AGRITECH, Vol. 37, No. 1, Februari 2017, Hal. 7-14 DOI: http://dx.doi.org/10.22146/agritech.17001 ISSN 0216-0455 (Print), ISSN 2527-3825 (Online) Tersedia online di https://jurnal.ugm.ac.id/agritech/

\title{
Pengaruh Penambahan Rempah dan Bentuk Minuman terhadap Aktivitas Antioksidan Berbagai Minuman Tradisional Indonesia
}

\author{
The Effect of Spices Addition and Beverage Forms on Antioxidant Activity of Indonesian Traditional Beverages
}

\author{
Aisyah Tri Septiana', Mohammad Samsi ${ }^{2}$, M. Mustaufik ${ }^{1}$ \\ 'Program Studi Ilmu dan Teknologi Pangan, Fakultas Pertanian, Universitas Jenderal Soedirman, \\ J1. Dr. Soeparno-Purwokerto 53123, Indonesia \\ ${ }^{2}$ Fakultas Peternakan, Universitas Jenderal Soedirman, Jl. Dr. Soeparno-Purwokerto 53123, Indonesia \\ Email: aisyah.septiana@yahoo.com
}

Submisi: 17 Juni 2015; Penerimaan: 26 Februari 2016

\begin{abstract}
ABSTRAK
Minuman tradisional Indonesia seperti minuman jahe, kunyit asam, beras kencur, dan minuman temulawak biasanya dibuat dengan tambahan berbagai rempah. Minuman tersebut dapat disajikan dalam bentuk cair maupun serbuk. Penelitian ini bertujuan untuk mengetahui pengaruh jenis minuman, penambahan rempah tambahan, dan bentuk minuman terhadap aktivitas antioksidan minuman. Jenis gula yang ditambahkan adalah gula nira. Jenis antioksidan yang diuji adalah total fenolik. Pengukuran aktivitas antioksidan dilakukan dengan uji penghambatan malonaldehid dan kapasitas penangkapan radikal DPPH. Hasil penelitian menunjukkan bahwa minuman tradisional Indonesia dapat menghambat oksidasi asam linoleat dan menangkap radikal bebas. Kapasitas penangkapan radikal bebas oleh minuman temulawak lebih besar dibandingkan minuman yang lain tetapi kemampuan penghambatan malonaldehid (MDA) oleh minumaan tradisional tidak berbeda. Total fenolik minuman temulawak cenderung lebih besar dibandingkan minuman tradisional yang lain. Penambahan rempah-rempah dapat meningkatkan kadar total fenolik minuman dan meningkatkan kapasitas penangkapan radikal bebas. Pembuatan minuman serbuk pada penelitian ini dapat menurunkan kadar total fenolik tetapi tidak menurunkan aktivitas antioksidan.
\end{abstract}

Kata kunci: Bentuk minuman; minuman tradisional Indonesia; rempah

\begin{abstract}
Indonesia traditional beverages such as minuman jahe, kunyit asam, beras kencur, and minuman temulawak are usually made with the addition of spices. They can be served in the form of liquid or powder. This research was aimed to study the effect of the beverage type, addition of spices, and the form of product on their antioxidant activity. The type of sugar used in this study was palm sugar juice. Total phenolic contents were measured to indicate the level of antioxidants. Measurement of antioxidant activity was conducted by analyzing malonaldehyde from linoleic acid and capturing capacity of DPPH radical. The results showed that Indonesian traditional beverage could inhibit the oxidation of linoleic acid and capture free radicals. Free radical capturing capacity of curcuma beverage greater than other beverages, but the malonaldehyde (MDA) inhibitor effect was not different. Total phenolic content of curcuma tended to be higher than the other traditional beverages. The addition of spices could raise the level of total phenolic content in beverages and increase free radical trapping capacity. Drying the beverages into powder could reduce the levels of total phenolic content and but did not reduce the antioxidant activity.
\end{abstract}

Keywords: Beverages; Indonesian traditional drink; spices 


\section{PENDAHULUAN}

Minuman tradisional Indonesia seperti minuman kunyit asam, minuman beras kencur, dan minuman temulawak biasa diproduksi oleh perajin jamu gendong, sedangkan minuman jahe biasa diproduksi oleh industri jamu dan rumah makan. Minuman tradisional tersebut secara empiris dapat digunakan untuk mengobati berbagai macam penyakit sehingga termasuk pangan fungsional.

Bahan dasar pembuat jamu seperti rempah-rempah dari spesies Zingiberaceae khususnya jahe, kunyit, temulawak dan kencur banyak ditemukan di Indonesia dan biasa digunakan sebagai obat tradisional. Khasiat rempah-rempah terhadap penyakit yang berhubungan dengan antioksidan antara lain jahe (Defang dkk., 2015) dan kunyit (Chainani, 2003)sebagai antirematik, temulawak sebagai antihepatitis (Devaraj dkk., 2014), serta kencur sebagai antiinflamasi (Hasanah dkk., 2011) dan relaksasi pembuluh darah (Umar dkk., 2011). Kunyit, jahe, dan temulawak (Tortosa dkk., 1999) juga terbukti dapat berfungsi sebagai penghambat oksidasi low density lipoprotein (LDL) dan akumulasi kolesterol pada makrofag sehingga diduga rempah-rempah tersebut dapat digunakan sebagai antioksidan dan antiaterosklerosis atau menghambat penyumbatan pembuluh darah.

Komponen jahe, kunyit, temulawak, dan kencur mempunyai aktivitas sebagai antioksidan. Terdapat 12 komponen fenolik pada jahe seperti gingerol, shogaol, dan diarilheptanoid yang memperlihatkan aktivitas antioksidan (Kikuzaki dan Nakatani, 1993). Kunyit dan temulawak yang mengandung komponen kurkuminoid dapat menghambat oksidasi asam linoleat (Jitoe dkk., 1992) dan menghambat oksidasi LDL (Septiana dkk., 2005). Kencur yang mengandung ethyl-p-metoxy cinnamate juga dapat berperan sebagai antioksidan (Sahoo dkk., 2014).

Minuman tradisional Indonesia seperti kunyit asam, temulawak, jahe, dan minuman beras kencur pada umumnya dibuat dengan mencampurkan bahan dasar kunyit, temulawak, jahe atau kencur dengan berbagai variasi rempah. Penambahan bahan dasar dapat meningkatkan aktivitas antioksidan sekaligus kualitas sensorisnya. Pada penelitian ini rempah-rempah yang ditambahkan adalah campuran dari jahe, kapulaga, cengkeh, dan sereh.

Cita rasa dari minuman juga dapat ditingkatkan dengan penambahan gula. Jenis gula yang sering ditambahkan pada pembuatan minuman tradisional adalah gula tebu. Adanya healthy food trend menyebabkan konsumen mulai meninggalkan jenis pemanis yang memiliki index glicemic (IG) yang tinggi. Pada penelitian ini pemanis yang digunakan adalah dari nira kelapa yang mempunyai IG lebih rendah dari gula tebu. Hasil penelitian Septiana dkk. (2014) juga menunjukkan bahwa aktivitas antioksidan minuman tradisional Indonesia yang dicampur gula tebu pada umumnya tidak berbeda dengan minuman yang dicampur nira kelapa.

Minuman yang berbentuk cairan tidak tahan lama disimpan, memerlukan pengemas yang mahal dan tempat penyimpanan yang luas sehingga perlu adanya pengembangan minuman berbentuk serbuk yang siap dikonsumsi hanya dengan penambahan air. Proses pengeringan kemungkinan dapat berpengaruh terhadap aktivitas antioksidan minuman serbuk. Penelitian ini dilakukan dengan tujuan untuk mengetahui pengaruh jenis minuman tradisional (minuman jahe, minuman kunyit asam, minuman temulawak, dan minuman beras kencur), penambahan rempah tambahan dan bentuk minuman (cair atau serbuk) terhadap aktivitas antioksidan minuman tradisional Indonesia.

\section{METODE PENELITIAN}

\section{Bahan dan Alat}

Bahan yang digunakan meliputi jahe, kunyit, asam jawa, temulawak, kencur, dan beras dari pasar Wage Purwokerto, nira dari desa Bojong-Purbalingga, dan air. Bahan kimia yang digunakan antara lain adalah etanol, Folin Ciocalteau, sodium karbonat, asam triklorasetat (TCA), asam tiobarbiturat (TBA), asam asetat, methanol, dan DPPH (1,1-difenil-2pikrilhidrazil) (Merck, Germany), asam linoleat (Sigma, United States), dan air bebas ion dari laboratorium terpadu Universitas Jenderal Soedirman.

Alat yang digunakan antara lain meliputi timbangan (Ohaus, United States), blender (Philip, Netherland), kompor (Rinae, Japan), panci (Bima, Indonesia), refraktometer (Krisbow, China), thermometer infrared (Krisbow, China), waterbath, spektrofotometer UV-Vis (Shimadzu 1240, Japan), incubator (Memmert, Japan), sentrifuse, botol coklat, tabung reaksi, dan beaker glass (Pyrex, Germany).

\section{Pembuatan Minuman}

Pembuatan minuman tradisional Indonesia (minuman jahe, kunyit asam, temulawak dan beras kencur) bentuk cair dimulai dengan sortasi bahan baku dan pencucian. Bahan baku berupa jahe, kunyit, temulawak, dan kencur yang berumur sekitar 9 bulan kecuali asam jawa, dengan atau tanpa rempah-rempah berupa jahe, kapulaga, cengkeh dan sereh dicuci, masing-masing dicampur air (1:1), dihancurkan dan diperas sehingga didapatkan ekstrak air. Nira kelapa yang telah dipanaskan sampai $30^{\circ}$ brix sebanyak 4 bagian dari bahan dasar dipanaskan sampai suhu $110^{\circ} \mathrm{C}$, dicampur ekstrak air dan dipanaskan sampai mendidih. Sirup kental yang dihasilkan ditambahkan air dengan perbandingan 1:8.

Pembuatan minuman tradisional serbuk menggunakan gula nira pada prinsipnya juga dilakukan dengan cara yang 
sama seperti pembuatan minuman tradisional cair. Nira kelapa dipanaskan pada suhu $110{ }^{\circ} \mathrm{C}$ dan dicampur ekstrak air jahe, kunyit, temulawak, atau kencur. Pemanasan dan pengadukan dilanjutkan sampai konsistensi kental dan timbul serabut-serabut $\left(118-121{ }^{\circ} \mathrm{C}\right)$, selanjutnya pemanasan dihentikan dan dilakukan penggerusan menggunakan batok kelapa sampai didapatkan bentuk kristal. Minuman serbuk diayak menggunakan pengayak 18 mesh dan dikeringkan menggunakan pengering cabinet bersuhu $55-60{ }^{\circ} \mathrm{C}$ seperti pembuatan gula semut dari nira. Sebelum dilakukan analisis, minuman serbuk sebanyak $20 \mathrm{~g}$ dicairkan dulu dengan penambahan air hangat hingga $200 \mathrm{~mL}$.

\section{Kadar Total Fenolik (Andarwulan dan Shetty, 1999)}

Pengujian kadar total fenolik minuman menggunakan asam tanat sebagai standar. Pembuatan kurva standar dilakukan dengan membuat seri pengenceran asam tanat dalam etanol (0 sampai $125 \mathrm{ppm}$ ). Untuk analisis asam tanat dan sampel minuman, masing-masing sampel maupun asam tanat sebanyak $1 \mathrm{~mL}$ dimasukkan dalam tabung reaksi, ditambahkan $1 \mathrm{~mL}$ etanol $95 \%, 5 \mathrm{~mL}$ air bebas ion dan $0,5 \mathrm{~mL}$ Folin Ciocalteau $50 \%$, dicampur dan didiamkan 5 menit. Setelah 5 menit ditambahkan $1 \mathrm{~mL}$ sodium karbonat $5 \%$, dicampur dan disimpan pada tempat gelap selama 60 menit. Sampel selanjutnya dicampur kembali dan diukur absorbansinya pada panjang gelombang $725 \mathrm{~nm}$.

\section{Aktivitas Antioksidan pada Asam Linoleat (Kikuzaki dan Nakatani, 1993)}

Analisis aktivitas antiosidan minuman tradisional dapat dilakukan berdasarkan penghambatan malonaldehida (MDA) dari hasil oksidasi asam linoleat. Sebelum pengukuran aktivitas antioksidan dilakukan inkubasi dan pengukuran absorbansi peroksida larutan blangko. Sebanyak $2 \mathrm{~mL}$ asam linoleat $50 \mathrm{~mm}$ dalam etanol 99,8 \%, $2 \mathrm{~mL}$ buffer fosfat 0,1 $\mathrm{M} \mathrm{pH} 7$ dan $1 \mathrm{~mL}$ air bebas ion dimasukkan pada vial gelap bertutup sekrup. Campuran tersebut diinkubasi pada suhu 37 ${ }^{\circ} \mathrm{C}$. Setiap 2 hari sekali dilakukan pengamatan absorbansi peroksida blangko menggunakan metode yang dilakukan Chen dkk (1996). Berdasarkan pengukuran absorbansi peroksida tersebut dapat ditentukan lama inkubasi untuk mencapai absorbansi peroksida blangko yang maksimal (misalnya $\mathrm{x}$ hari).

Pengamatan absorbansi MDA dilakukan setelah inkubasi campuran asam linoleat seperti pada pengukuran blangko dengan penambahan $2 \%$ minuman tradisional selama $\mathrm{x}+2$ hari. Pengukuran absorbansi MDA dilakukan menggunakan metode Kikuzaki dan Nakatani (1993) dengan modifikasi. Persen penghambatan MDA dihitung dengan rumus:

Persen penghambatan $=\frac{\text { Absorbansi Kontrol }- \text { Absorbansi Sampel }}{\text { Absorbansi Kontrol }} \times 100 \%$

\section{Kapasitas Penangkapan Radikal Bebas (Sheikh dkk., 2009)}

Larutan minuman tradisional dipersiapkan dengan melarutkan minuman pada konsentrasi 1.250, 2.500, 5.000, $10.000,20.000$ dan $40.000 \mathrm{ppm}$ dalam metanol. Sebanyak $2 \mathrm{~mL}$ larutan ekstrak tersebut dicampur dengan $2 \mathrm{~mL}$ larutan DPPH $0,16 \mathrm{~mm}$ dalam metanol. Campuran divorteks selama 1 menit dan dibiarkan selama 30 menit sebelum absorbansinya diukur pada panjang gelombang $517 \mathrm{~nm}$. Penurunan absobansi menunjukkan peningkatan kemampuan menangkap radikal DPPH. Kemampuan untuk menangkap radikal DPPH dihitung dengan persamaan:

Kapasitas penangkapan radikal (\%) $=\frac{\text { Abs. Kontrol }- \text { Abs.Sampel }}{\text { Absorbansi Kontrol }} \times 100 \%(2)$ Keterangan :

Abs $=$ Absorbansi

Penentuan nilai $\mathrm{IC}_{50}$ dibuat berdasarkan kurva hubungan antara konsentrasi sampel (X) dan kapasitas penangkapan radikal bebasnya $(\mathrm{Y})$ yang berupa persamaan garis lurus. Nilai $\mathrm{IC}_{50}(\mathrm{ppm}$ DPPH) diperoleh dengan memasukkan $50 \%$ nilai $Y$ pada persamaan garis yang diperoleh.

\section{Rancangan Percobaan (Sudjana, 1989)}

Penelitian dilaksanakan secara eksperimental menggunakan rancangan dasar Rancangan Acak Kelompok (RAK) pola faktorial $4 \times 2 \times 2$. Pengelompokan dilakukan sebanyak 3 kali berdasarkan pembuatan minuman. Faktor yang dicoba meliputi jenis minuman $(\mathrm{M})$ : minuman jahe (M1), minuman kunyit asam (M2), minuman temulawak (M3), dan minuman beras kencur (M4), tambahan rempah (tanpa tambahan rempah dan dengan tambahan rempah), dan bentuk minuman (serbuk dan cair). Analisis yang dilakukan adalah total fenolik, penghambatan malonaldehida dan kapasitas penangkapan radikal DPPH.

\section{HASIL DAN PEMBAHASAN}

\section{Kadar Total Fenolik}

Total fenolik pada dasarnya adalah senyawa fenolik yang umumnya pada tumbuhan berupa senyawa polifenolik maupun fenolik sederhana (Pratt dan Hudson, 1990). Pengaruh jenis minuman tradisional (a) tambahan rempah (b) dan bentuk minuman (c) terhadap total fenolik minuman tradisional disajikan pada Gambar 1.

Minuman jahe, kunyit, temulawak, dan beras kencur mempMinuman jahe, kunyit, temulawak dan beras kencur mempunyai kadar total fenolik yang tidak berbeda secara nyata. Hal ini diduga karena pengukuran kadar total fenolik menggunakan metode Folin Ciocalteau yang digunakan 


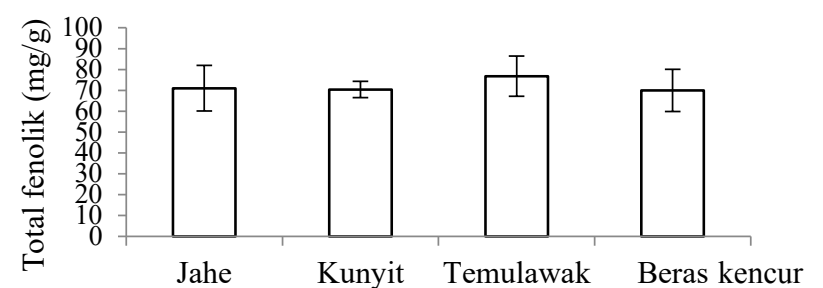

Jenis minuman tradisional

(a)

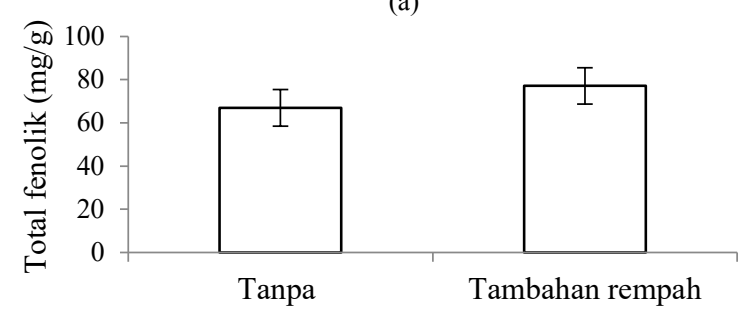

Tambahan rempah

(b)

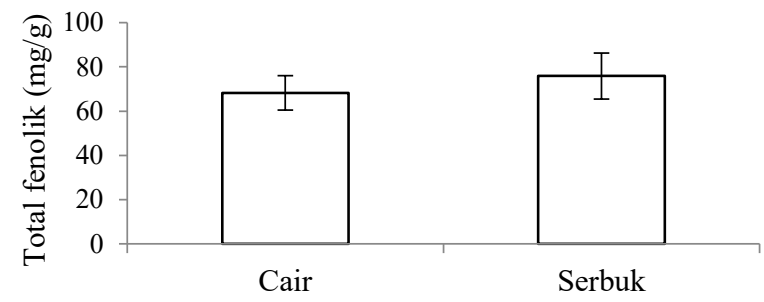

Bentuk minuman

(c)

Gambar 1. Pengaruh jenis minuman tradisional (a) tambahan rempah (b) dan bentuk minuman (c) terhadap total fenolik minuman tradisional

pada penelitian ini juga dapat mendeteksi gula reduksi yang dijumpai pada minuman tersebut sebagai senyawa fenolik. Gula reduksi dapat terbentuk dari gula kelapa yang ditambahkan selama pengolahan minuman. Meskipun jumlah gula kelapa yang ditambahkan pada minuman tradisional sama, tetapi $\mathrm{pH}$ minuman berbeda sehingga kadar gula reduksi minuman tersebut juga berbeda. Menurut metode Folin Ciocalteau, pengukuran fenol dengan kolorimeter berdasarkan pada reduksi kimia dari reagent campuran tungsten dan molybdenum. Produk reaksi Folin Ciocalteau menghasilkan metal oksida yang menimbulkan warna biru pada panjang gelombang $765 \mathrm{~nm}$ seperti pada penentuan jumlah fenol wine. Terdapat kesamaan antara gula reduksi dengan fenol dalam mereduksi logam dari campuran tungsten dan molybdenum dari pereaksi folin ciocalteau sehingga terbentuk metal oksida yang dapat meningkatkan warna biru (Wrolstad, 2005). Hal ini menyebabkan kadar total fenolik minuman secang yang ditambah gula sukrosa lebih besar dibandingkan minuman secang tanpa gula sukrosa (Zulfahmi dan Nirmagustina, 2012).
Penambahan rempah-rempah meningkatkan kadar total Penambahan rempah-rempah meningkatkan kadar total fenolik minuman tradisional karena rempah-rempah berupa jahe, kapulaga, cengkeh, dan sereh masing-masing mengandung senyawa fenolik yang cukup tinggi. Hasil selaras terdapat pada minuman secang yang ditambah jahe, cengkeh dan sereh yang mempunyai kadar total fenol lebih besar dibandingkan minuman secang tanpa penambahan rempah-rempah tersebut (Nirmagustina dkk., 2011).

Rerata kadar total fenolik minuman tradisional yang disajikan dalam bentuk cair lebih besar dibandingkan dengan total fenolik minuman serbuk. Pemanasan dan pengkristalan rempah-rempah selama pembentukan minuman tradisional serbuk menyebabkan penurunan kadar total fenolik minuman yang dihasilkan. Diduga pengkristalan minuman menyebabkan senyawa fenolik terikat dengan komponen lain sehingga gugus fenolik pada cincin benzennya tidak terdeteksi.

\section{Kapasitas Penangkapan Radikal Bebas}

Kapasitas penangkapan radikal bebas diukur berdasarkan kemampuan minuman tradisional dalam menangkap radikal DPPH (1,1-difenil-2-pikril hidrazil). DPPH adalah suatu radikal yang cukup stabil berwarna ungu pada panjang gelombang $517 \mathrm{~nm}$. Ketika radikal DPPH bereaksi dengan suatu senyawa antioksidan yang dapat mendonorkan atom hidrogen, DPPH tersebut akan tereduksi menjadi DPPH-H. Kapasitas penangkapan radikal bebas ditunjukkan dengan persentase berkurangnya warna ungu dari DPPH (Kim, 2005).

Kapasitas penangkapan radikal DPPH oleh minuman tradisional dengan perlakuan perbedaan jenis minuman tradisional, tambahan rempah, dan bentuk minuman pada berbagai konsentrasi minuman disajikan pada Gambar 2. Pada umumnya peningkatan konsentrasi minuman tradisional dari 1,25 sampai 40 ppt dapat meningkatkan kapasitas peningkatan radikal DPPH minuman tradisional. Berdasarkan hal tersebut perbedaan kapasitas penangkapan radikal DPPH diuji pada konsentrasi $40 \mathrm{ppt}$ dan $\mathrm{IC}_{50}$. Nilai $\mathrm{IC}_{50}$ menunjukkan konsentrasi minuman tradisional pada saat minuman mempunyai kapasitas penangkapan radikal bebas sebesar $50 \%$.

Kapasitas penangkapan radikal bebas oleh minuman tradisional pada konsentrasi 40 ppt dapat dilihat pada Gambar 3 dan $\mathrm{IC}_{50}$ pada Gambar 4. Hasil penelitian pada Gambar 3 menunjukkan bahwa pada konsentrasi minuman $40 \mathrm{ppt}$, jenis minuman dan penambahan rempah berpengaruh nyata terhadap kapasitas penangkapan radikal bebas. Sedangkan bentuk minuman tidak berpengaruh terhadap kapasitas penangkapan radikal bebas maupun $\mathrm{IC}_{50}$ minuman tradisional Indonesia. 


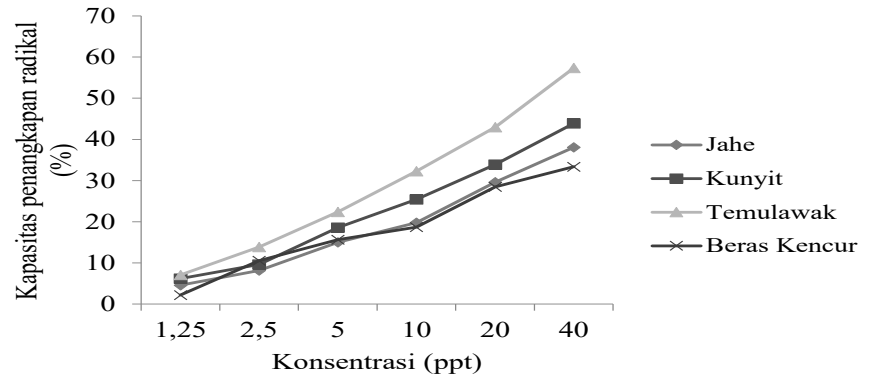

(a)

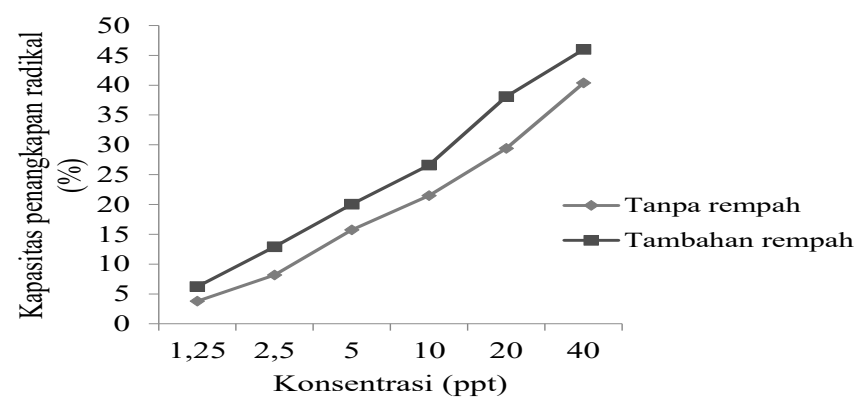

(b)

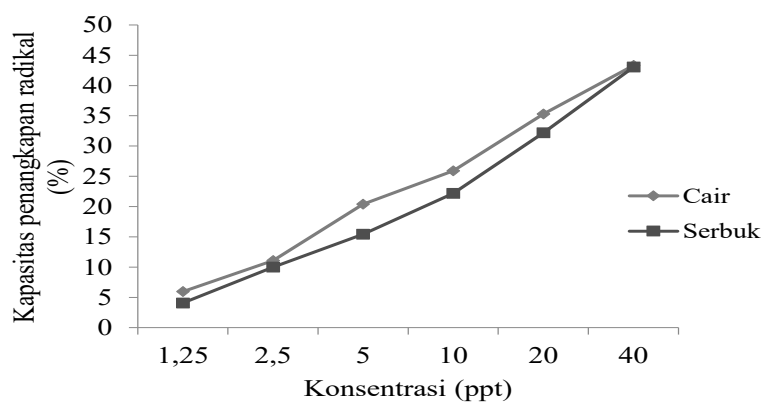

(c)

Gambar 2. Kapasitas penangkapan radikal DPPH pada berbagai konsentrasi minuman tradisional perlakuan jenis minuman (a), tambahan rempah (b) dan bentuk minuman (c)

Minuman temulawak mampu menangkap radikal DPPH lebih besar dibandingkan minuman kunyit asam, minuman jahe dan minuman beras kencur. Hasil penelitian Setyowati dan Suryani (2013) juga menunjukkan bahwa minuman ekstrak etanol temulawak mempunyai kapasitas scavanger radikal bebas (\% RSA) lebih besar dibandingkan ekstrak etanol kunyit.

Kapasitas penangkapan radikal bebas dari minuman tradisional yang ditambahkan berbagai jenis rempah (berupa campuran jahe, kapulaga, sereh, dan cengkeh) lebih besar dibandingkan kapasitas penangkapan radikal bebas oleh minuman tradisional tanpa tambahan rempah. Sereh (Yusuf, 2001), jahe (Kikuzaki dan Nakatani, 1993), cengkeh (Nurjannah dkk., 2013), dan kapulaga (Winarsi, 2014) masing-masing mempunyai aktivitas antioksidan dari senyawa fenolik. Diduga senyawa fenolik tersebut mempunyai

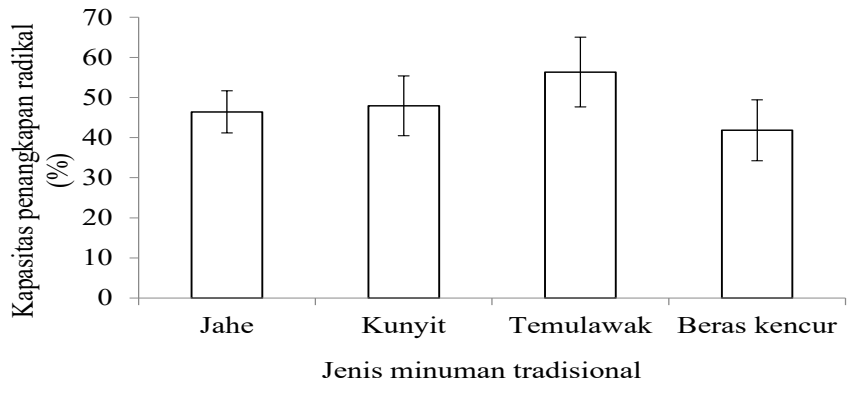

(a)

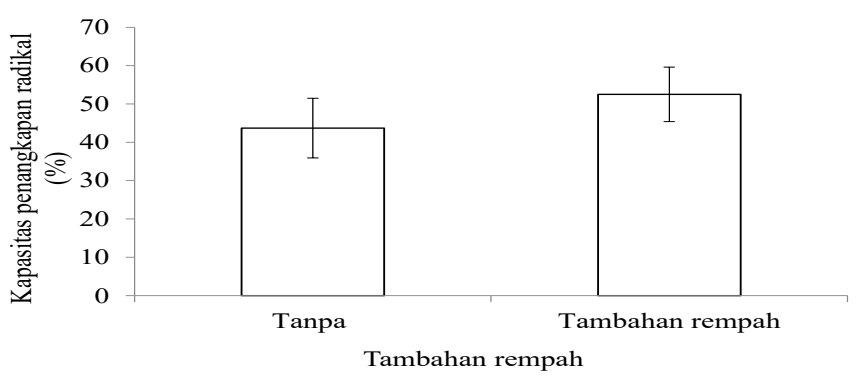

(b)

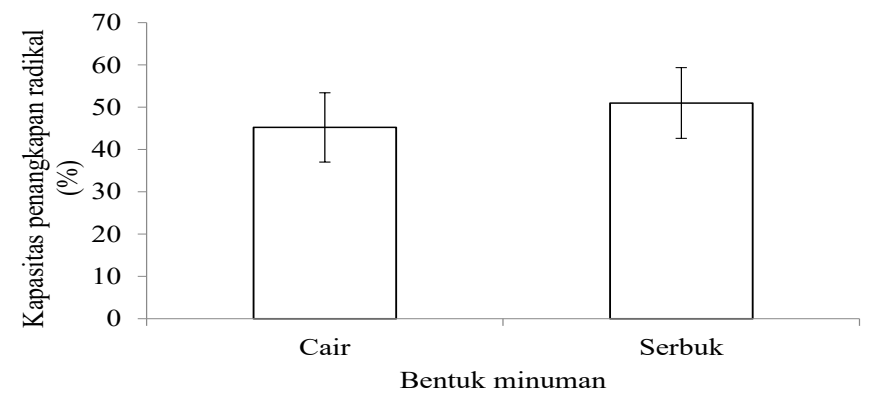

(c)

Gambar 3. Pengaruh jenis minuman (a), tambahan rempah (b) dan bentuk minuman (c) terhadap penangkapan radikal bebas (\%) minuman

aktivitas antioksidan dengan cara menangkap radikal bebas dan memberikan efek sinergisme ketika dicampurkan pada minuman tradisional Indonesia.

Kapasitas penangkapan radikal bebas DPPH oleh minuman tradisional cair pada konsentrasi 40 ppt maupun $\mathrm{IC}_{50}$ tidak berbeda dengan kapasitas penangkapan radikal bebas DPPH oleh minuman tradisional serbuk. Pemanasan dan pengkristalan pada pembuatan minuman tradisional serbuk tidak memberikan pengaruh terhadap kapasitas penangkapan radikal bebasnya. Hal ini diduga karena gula yang ditambahkan dalam minuman memberikan perlindungan terhadap kerusakan komponen bioaktif minuman tradisional selama pengkristalan menggunakan pemanasan.

Kemampuan antioksidan sebagai penangkap radikal bebas dikaitkan dengan kemampuan antioksidan tersebut sebagai donor proton. Berbagai senyawa fenolik dapat 
berperan terhadap kapasitas penangkapan radikal bebas dengan kapasitas yang berbeda-beda.

Hubungan kadar total fenolik dengan kapasitas penangkapan radikal bebas pada konsentrasi 40 ppt maupun nilai $\mathrm{IC}_{50}$ pada perlakuan jenis rempah berkorelasi nyata. Komponen fenolik dapat berperan sebagai antioksidan dengan cara mendonorkan proton hidrogen (antioksidan primer), donor elektron (pereduksi), mengikat ion logam, dan mengikat radikal bebas seperti radikal hidroksil, anion superoksida maupun $\mathrm{H}_{2} \mathrm{O}_{2}$.

$\alpha$-Tokoferol yang digunakan sebagai pembanding memiliki aktivitas penangkapan radikal bebas DPPH yang lebih tinggi dari semua jenis minuman yaitu sebesar 80,20 \%. Pokorny dkk. (2001) menyatakan bahwa vitamin E adalah senyawa fenolik alami yang berfungsi sebagai penangkap radikal. Hasil penelitian Kim (2005) menunjukkan bahwa vitamin E memiliki efek penangkapan radikal DPPH sebesar 95,17 \% pada konsentrasi 160 ppm yang menunjukkan pada konsentrasi rendah vitamin $E$ telah memberikan efek penangkapan radikal yang tinggi.

\section{Penghambatan Malonaldehid (MDA)}

Aktivitas penghambatan oksidasi asam linoleat diukur berdasarkan penghambatan malonaldehid (MDA). Pengaruh jenis minuman tradisional (a), bahan tambahan rempah (b) dan bentuk minuman (c) terhadap penghambatan MDA disajikan pada Gambar 4.

Menurut Fennema (1996), MDA merupakan salah satu hasil dekomposisi hidroperoksida. MDA dapat dibentuk dari radikal peroksil $\left(\mathrm{ROO}^{\bullet}\right)$ dari lipid tidak jenuh ganda. Dengan demikian, komponen aktif dalam minuman jahe, kunyit asam, temulawak, dan beras kencur mempunyai kemampuan menghambat pembentukan radikal peroksil (ROO`) sebagai produk oksidasi primer sehingga dapat menghambat pembentukan MDA.

Jenis minuman tradisional, penambahan rempah maupun pembuatan minuman bentuk serbuk tidak berpengaruh nyata terhadap penghambatan pembentukan MDA oleh minuman tradisional. Kemampuan terhadap penghambatan MDA oleh minuman jahe, kunyit, temulawak dan beras kencur tidak berbeda nyata. Hal ini berbeda dengan aktivitas antioksidan ekstrak jahe dan ekstrak temulawak menyebabkan penghambatan MDA oleh ekstrak jahe lebih tinggi dibandingkan ekstrak temulawak (Septiana, 2004). Komponen bioaktif pada minuman jahe lebih mudah rusak oleh pemanasan dibandingkan komponen temulawak. Perbedaan aktivitas antioksidan minuman ini dengan aktivitas antioksidan ekstraknya diduga karena adanya penambahan pemanis berupa gula nira atau gula kelapa. Gula kelapa mengandung protein. Menurut Ma'ruf (1990), malonaldehid

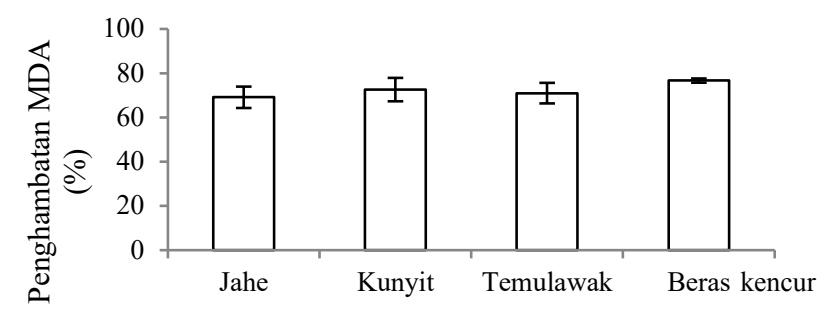

Jenis minuman tradisional

(a)

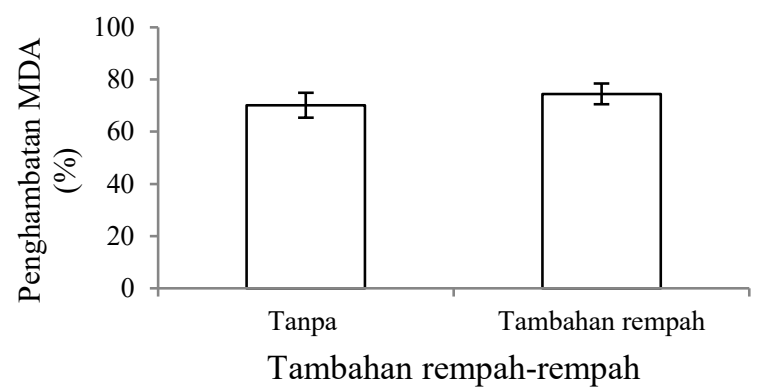

(b)

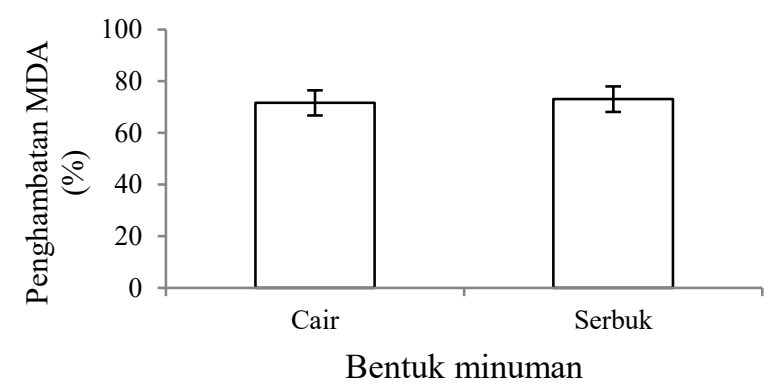

(c)

Gambar 4. Pengaruh jenis minuman tradisional (a), tambahan rempah (b), dan bentuk minuman (c) terhadap penghambatan malonaldehid

dari hasil oksidasi lemak bersifat tidak stabil. Malonaldehid sangat reaktif terhadap protein dan asam amino.

Hasil aktivitas antioksidan berdasarkan penghambatan malonaldehid ini berbeda dengan hasil aktivitas antoksidan berdasarkan hasil kapasitas penangkapan radikal dari minuman. Hasil penelitian ini selaras dengan hasil penelitian Dedin dkk. (2006) pada aktivitas antioksidan melanoidin kecap manis. Selain dalam kecap, melanoidin hasil reaksi Maillard antara protein dan gula reduksi banyak dijumpai pada gula kelapa yang digunakan sebagai pemanis pada minuman tradisional ini.

\section{KESIMPULAN}

Minuman tradisional Indonesia berupa minuman jahe, minuman kunyit asam, minuman temulawak, dan minuman beras kencur dapat berfungsi sebagai antioksidan pada asam linoleat dengan cara menangkap radikal bebas. 
Kapasitas penangkapan radikal bebas oleh minuman temulawak lebih besar dibandingkan minuman yang lain tetapi kemampuan penghambatan malonaldehid (MDA) oleh minumaan tradisional tidak berbeda. Kadar total fenolik minuman temulawak cenderung lebih besar dibandingkan minuman tradisional yang lain. Penambahan rempah-rempah berupa campuran jahe, kapulaga, sereh dan cengkeh dapat meningkatkan kadar total fenolik minuman dan meningkatkan kapasitas penangkapan radikal bebas. Pembuatan minuman serbuk pada penelitian ini dapat menurunkan kadar total fenolik tetapi tidak menurunkan aktivitas antioksidan.

\section{DAFTAR PUSTAKA}

Andarwulan, N. dan Shetty, K. (1999). Phenolic content in differentiated tissue culture of transformed and agrobacterium-transformed roots of anise (Pimpinella anisum L). Journal of Agricultural and Food Chemistry 47: 1776-1780.

Chainani, N. (2003). Safety and anti-inflamatory actiivit of curcumin: A component of turmeric (Curcuma longa). The Journal of Alternative and Complmentary Medicine 9(1): 161-168.

Chen, H.M., Muramoto., Yamauchi dan Nokihara. (1996). Antioxidant activity of designed pebtides based on the antioxidative pebtides isolated from digests of a soybean protein. Journal of Agricultural and Food Chemistry 44: 2619-2623.

Dedin, F.R., Fardiaz, D., Apriyantono, A. dan Andarwulan, N. (2006). Isolasi dan karakterisasi melanoidin kecap manis dan peranannya sebagai antioksidan. Jurnal Teknologi dan Industri Pangan 17(3): 204-2010.

Defang, L., Mingyang, G., Yonghe, H., Taihua, L., Jiao, Y., Yong, L., Mingdong, Y., Ming, Y., Jun, Z. dan Linglin, G. (2015). Effect of Sanhuangwuji powder, anti-rheumatic drugs, and ginger-partitioned acupoint stimulation on the treatment of rheumatoid arthritis with peptic ulcer: a randomized controlled study. Journal of Traditional Chinese Medicine 35(3): 273-280.

Devaraj, S., Ismail, S., Ramanathan, S. dan Yam F.M. (2014). Investigation of antioxidant and hepatoprotective acivity of standardized Curcuma xanthorrhiza rhizome in carbon tetrachloride-induced hepatic damaged rats. The Scientific World Journal 2014(2014): 1-8.

Fennema, O.R. (1996). Food Chemistry $3^{\text {rd }}$ Ed. Marcel Dekker Inc., New York.

Hasanah, A.N., Nazarudin, F., Febrina, E. dan Zuhrotun, A. (2011). Analisis kandungan minyak atsiri dan uji aktivitas antiinflamasi ekstrak rimpang kencur (Kaempferia galanga 1.). Jurnal Matematika dan Sains 16(3): 147-152.

Jitoe, A., Masuda, T., Tengah, I.G.P., Suprapta, D.N., Gara, I.W. dan Nakatani, N. (1992). Antioxidant activity of tropical ginger extracts and analysis of the contained curcuminoids. Journal of Agricultural and Food Chemistry 40: 1337-1340.

Kikuzaki, H. dan Nakatani, N. (1993). Antioxidant effect of some ginger consituents. Journal of Food Science 58(6): 1407-1410.

Kim, O.S. (2005). Radical scavenging capacity and antioksidant activity of the $\mathrm{E}$ vitamer fraction in rice bran. Journal of Food Science 70(3): 208-213.

Lai, L.S., Chou, S.T. dan Chao, W.W. (2001). Studies on the antioxidative activities of hsian tsao (Mesona procumbens Heinsl) leaf gum. Journal of Agricultural and Food Chemistry 49(2): 963-968.

Nirmagustina, D.E., Zulfahmi dan Oktafrina (2011). Sifat organoleptik dan kandungan total fenol minuman rempah tradisonal (minuman secang). Jurnal Teknologi Industri dan Hasil Pertanian 16(1): 22-33.

Nurjannah, D.A., Retnowati, R. dan Juwono, U.P. (2013). Aktivitas antioksidan dari minyak bunga cengkeh (Syzygium aromaticum) kering berdasarkan aktivias antiradikal yang ditentukan menggunakan Electron Spin Resonance. Kimia Student Jurnal 1(2): 283-288.

Pratt, D.E. dan Hudson, B.J.F. (1990). Natural antioxidant not exploited commercially. Dalam: B.J.F. Hudson (Ed.), Food Antioxidant. Elsevier, London.

Pokorny, J. dan Korczak, J. (2001). Preparation of natural antioxidant. Dalam: Gordon, M. (Ed.). Antioxidant in Food. CRC Press, New York, Washington D.C.

Sahoo, S., Parida, R., Singh, S., Padhy, R.N. dan Nayak, S. (2014). Evaluation of yield, quality and antioxidant activity of essential oil of in vitro propagated Kaempferia galanga Linn. Journal of Acute Disease 2014: 124-130.

Septiana, A.T. (2001). Aktivitas Ekstrak Jahe (Zingiber officinale Roscoe) dalam Pencegahan Oksidasi Lipoprotein Densitas Rendah (LDL) dan Akumulasi Kolesterol pada Makrofag Secara In Vitro. Disertasi Program Pasca Sarjana Institut Pertanian Bogor, Bogor.

Septiana, A.T., Dwiyanti, H., Muchtadi, D. dan Zakaria, F.R. (2004). Kajian Antioksidan Zingiberaceae sebagai Penghambat Oksidasi Lipoprotein Densitas Rendah (LDL) dan Akumulasi Kolesterol pada Makrofag. 
Laporan Penelitian Hibah Pekerti Tahun 1. Fakultas Pertanian. Universitas Jenderal Soedirman, Purwokerto.

Septiana, A.T., Dwiyanti, H., Muchtadi, D., dan Zakaria, F.R. (2005). Kajian Antioksidan Zingiberaceae sebagai Penghambat Oksidasi Lipoprotein Densitas Rendah (LDL) dan Akumulasi Kolesterol pada Makrofag. Laporan Penelitian Hibah Pekerti Tahun 2. Fakultas Pertanian. Universitas Jenderal Soedirman, Purwokerto.

Setyowati, A. dan Suryani, C.L. (2013). Peningkatan kadar kurkuminoid dan aktivitas antioksidan minuman instan temulawak dan kunyit. Agritech 33(4): 363-370.

Sheikh, T.Z.B., Yong, C.L. dan Lian, M.S. (2009). In vitro antioxidant activity of the hexane and methanolic extracts of Sargassum baccularia and Cladophora patentiramea. Journal of Applied Sciences 13(9): 24902493.

Sudjana (1989). Desain dan Analisis Eksperimen. Tarsito, Bandung.

Tortosa, M.C., Mesa, M.D., Aguilera, M.C., Quiles, J.L., Baro, L., Tortosa, C.L.R., Martinus-Victoria, E. dan Gil, A. (1999). Oral administration of turmeric extract inhibits LDL oxidation and has hypocholesterolemic effects in rabbits with experiment atherosclerosis. Atherosclerosis 147: $371-378$.
Umar, M.I., Zaini, M., Sadikun, M., Altaf, R. dan Iqbal, M.A. (2011). Phytochemistry and medicine properties of Kaempferia galangal L (Zingiberaceae) extract. African Journal of Pharmacy and Pharmacology 5(14): 1638-1647.

Winarsi, H. (2014). Antioksidan Daun Kapulaga. Graha Ilmu, Yogyakarta.

Wrolstad, R.E. (2005). Handbook of Food Analytical Chemistry. John Wiley and Sons, Inc. New Jersey.

Yusuf, R.R. (2001). Formulasi, Karakterisasi Kimia dan Uji Aktivitas Antioksidan Sari Jahe (Zingiber officinale Roscoe) dan Sari Sereh Dapur (Cymbopogon flexuosus). Skripsi. Fakultas Teknologi Pertanian. Institut Pertanian Bogor, Bogor.

Zulfahmi, dan Nirmagustina, D.E. (2012). Pengaruh sukrosa terhadap kandungan total fenol minuman rempah tradisional (minuman secang). Jurnal Penelitian Pertanian Terapan 12(2): 125-130. 